
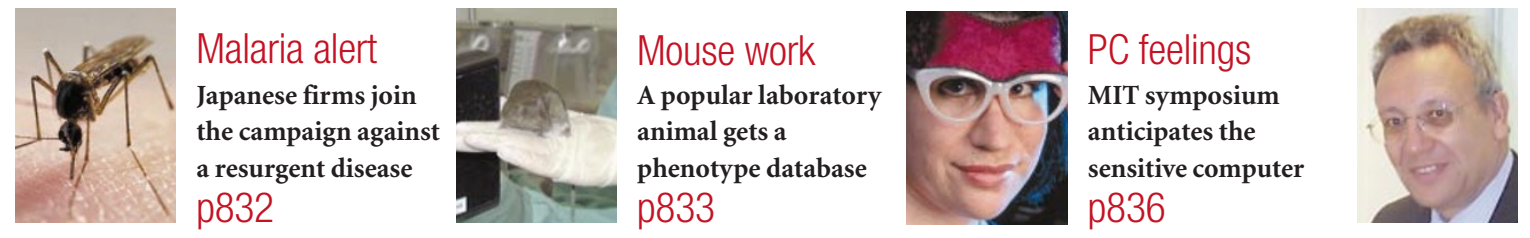

New broom

Profile of Europe's

new research

commissioner

p837

\title{
Developing countries look for guidance in GM crops debate ...
}

\section{Washington}

Developing countries have called on the Consultative Group on International Agricultural Research (CGIAR) - an influential federation of agricultural research centres to develop guidelines for the research, trial and commercialization of genetically modified (GM) crops.

At a meeting in Washington last week, hosted by CGIAR and the US National Academy of Sciences, agricultural researchers and research administrators appealed to CGIAR to provide guidance to help poorer countries address the global debate over the application of agricultural biotechnology.

With consumers' groups, largely from Europe, and purveyors of transgenic crops, mainly in the United States, battling to determine the global acceptability of the new technology, many speakers warned that the interests of poor nations are being brushed aside.

Even the most powerful developing countries are seeking help from CGIAR, a network of 16 major agricultural centres sponsored by the World Bank, the Food and Agriculture Organization and the United Nations, which spent \$340 million last year on agricultural research.

Manju Sharma, secretary for biotechnology at India's Ministry of Science and Technology, called on CGIAR to publish guidelines on scientific research, field trials and commercialization to help governments set policies on agricultural biotechnology.

Speakers at the meeting also said that developing countries will depend on CGIAR to help counter the influence of the private corporations that control patents and information on transgenic crops.

Villoo Morawala-Patell, a professor at the University of Agricultural Sciences, Bangalore, India, said that public resistance is "not so much to GM food as to big industry". She called on CGIAR to "set up a parallel and alternative technology base" to that established by the corporations "in which the status of the farmer is protected".

CGIAR demonstrated its influence on the global GM food debate earlier this year, when it called on developing countries to boycott

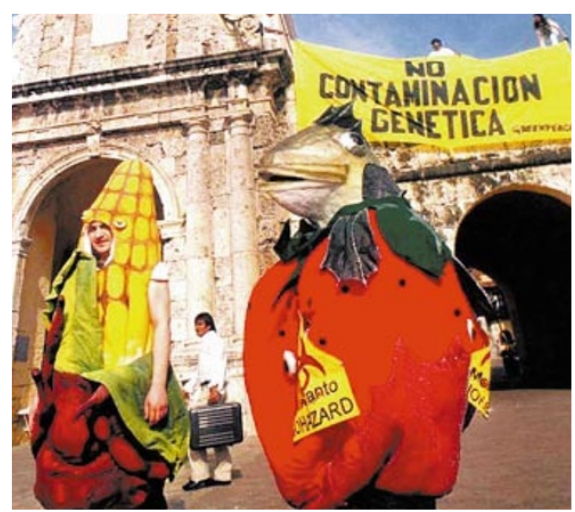

Pressure point: protestors in Colombia lobby talks on regulating GM trade earlier this year.

the 'Terminator' gene technology, which Monsanto has since abandoned.

CGIAR held the meeting of several hundred of its centres' officials and other inter- ested parties to help develop its approach to transgenic crops. "Everyone is waiting for them, because they are such a big actor," says Calestous Juma, a professor at Harvard University and a special adviser to the group.

"They can't sit on the fence anymore, because everyone is hacking away at the fence." But the "conflicting interests" of CGIAR's donors, who include the major industrialized countries, make it hard to determine a policy on GM crops, says Juma.

Older biotechnology tools, such as genetic markers in plant breeding, are firmly established in the centres. But less than ten per cent of their work currently involves transgenics, say officials.

Many of the research centres are determining whether and how to take their first transgenic crops into field trials. As the Washington meeting took place, for example, rice farmers were invited to the International

\section{... as Rockefeller head warns of backlash}

\section{San Francisco}

Public opposition to agricultural biotechnology in the industrial world could rob developing countries of the fruits of genetic research that are vital to their survival, according to Gordon Conway, the president of the Rockefeller Foundation.

Conway, who came to the foundation 18 months ago from a position as vice-chancellor of the University of Sussex in Brighton, England, is a renowned agricultural ecologist. He urges biotech multinationals to do more to address the ethical, economic, environmental and safety issues posed by crop manipulation, before a hostile public shuts down their operations.

He argues that the genetic engineering of food poses risks such as outcrossing into wild species and the creation of new viruses - that should be examined more closely. But he also emphasizes the potential benefits.

In an effort to address these issues, the Rockefeller is committing more than $\$ 1$ million a year to fund projects that foster constructive dialogue. In particular, the New York-based foundation aims to help developing countries become better informed and take a stronger role in policy discussions, so they can decide for themselves what level of risk is appropriate without becoming guinea-pigs for wealthier nations

For example, the foundation recently gave $\$ 260,000$ to the African Centre for Technology Studies in Nairobi for a two-year project intended to help six
African governments develop their positions on genetic engineering and biodiversity.

Conway says the

biotechnology industry has shown a new willingness to respond to argument. Monsanto, for example, recently promised not to develop the 'Terminator' technology that would make its seeds sterile and force farmers to buy new ones every year.

In early October, Monsanto's chief executive Robert Shapiro acknowledged the need to find common ground with biotechnology's opponents. He told the Greenpeace Business Conference in London that, until now, Monsanto had "irritated and antagonized more people than we have persuaded".

Du Pont, based in Wilmington, Delaware, plans to form an 
Centre for Tropical Agriculture (CIAT) at Cali, Colombia, to discuss trials of the centre's first transgenic rice plant, resistant to the hoja blanca virus that damages rice crops in Latin America.

Such trials are strongly supported by researchers and research administrators across the CGIAR network. But private corporations have found them difficult to put into practice. In Brazil an injunction by Greenpeace has stalled Monsanto's plans to test five breeds of soybean, and in Mexico concern has focused on the effect of GM maize on wild strains of the plant.

The extent to which the publicly funded CGIAR network should support either field trials or the commercialization of GM crops was fiercely debated. Brian Johnson of English Nature called for a moratorium on commercialization, and Fred Gould, an ecologist at North Carolina State University, warned that developing countries are ill-equipped to cope with unforeseen environmental problems that may arise from the crops.

But supporters of transgenic technology, such as Klaus Leisinger of Novartis, accused detractors of delaying nutritional improvements that could save thousands of lives.

Leisenger attacked what he termed "bioMcCarthyism”. But Mark Sagoff, an ethicist at the University of Maryland, accused Leisinger of "fundamentalism" and argued that poverty is the real cause of malnutrition.

There was agreement with Sagoff's point that the 'safety' of GM crops is not the primary issue. As James Cook, a plant pathologist at Washington State University who represented the US National Academy at the meet- ing, put it: "This whole debate isn't really about safety. Safety is the card which is played to get the deeper political and economic issues on to the table."

These issues include the fact that none of the first-generation transgenic crops are of much use to farmers in poor countries rather, they will extend the productivity advantages enjoyed by heavily subsidized farmers in industrialized countries.

Another issue is the lack of technical knowledge in poor countries. But the most pressing concern is the imbalance of negotiating strength between the corporations that pioneered transgenic crops and farmers, scientists and governments in poor countries.

The developing world "must rely on the international organizations" to protect its rights, says Behzad Ghareyazie, director of the Agricultural Biotechnology Research Institute of Iran. But some speakers doubted whether even CGIAR has much negotiating power compared with the corporations.

Richard Jefferson, director of the Centre for the Application of Molecular Biology in International Agriculture in Australia, called on CGIAR to give its researchers "freedom to operate" in the face of ever-tightening restraints on their work.

Ismail Serageldin, chairman of CGIAR, was absent - he was in Paris, seeking to become head of the United Nations Education, Scientific and Cultural Organization (see page 833). Alex McCalla, director of rural development at the World Bank, summed up on his behalf, saying: "We've heard nothing that shakes my conviction that biotechnology has tremendous potential.” Colin Macilwain advisory group to review its activities in agricultural biotechnology and to provide a critique of the company's performance.

Conway praises these moves as "a good first step". But he urges the companies to do more, for example by donating enabling technologies to developing countries, by accepting 'plant variety' protection instead of seeking patents, and by using part of their profits to assist publicsector research.

Labelling should be considered a 'freedom of information' issue, says Conway, in that the public has a right to know what it is eating and to choose whether to buy genetically engineered foods. Companies may decide not to develop certain technologies because of social concerns, he adds. He urges governments, corporations, activists and scientists from the

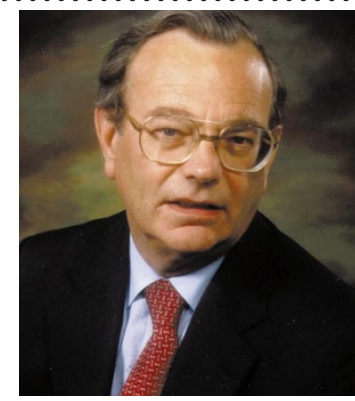

Conway: fears public hostility to GM will harm development.

developed and the developing world to pinpoint significant issues and negotiate solutions.

Behind Conway's suggestions is a concern that public opposition to private initiatives could undermine public programmes, such as those financed by the Rockefeller Foundation.

"We are concerned that the public sector science is being constrained on the one end by limited access to the technologies, and on the other by increasing wariness about getting involved because [biotechnology] is so unpopular," said Gary Toenniessen, deputy director of agricultural services for Rockefeller.

Crop research that could help poor countries is not being pursued by companies, and some of the aid donors are becoming increasingly squeamish about it, he says.

The Rockefeller Foundation has spent more than $\$ 100$ million on plant biotechnology research, focusing on helping the poor. Scientists receiving its funds recently announced that they had used genetic modification to make rice produce $\beta$-carotene (which is converted to vitamin $A$ ) and iron, nutrients lacking in the diets of developing countries. After checks on its environmental and human effects, the rice will be donated to developing countries. Sally Lehrman

\section{Japanese companies join international fight against malaria}

\section{Tokyo}

Twelve Japanese pharmaceutical companies announced this week that they are joining with the World Health Organization (WHO) and Japan's Ministry of Health and Welfare to launch an initiative to identify potential drugs against malaria.

JPMW - which stands for Japanese Pharma, Ministry of Health and Welfare and WHO - will become part of 'Roll Back Malaria', a programme launched last year by WHO to create a global strategy for controlling malaria.

JPMW's activities, to be jointly funded by WHO and Japan's health ministry, will complement other initiatives in the Roll Back Malaria programme. Among these is the New Medicines for Malaria Venture, a public/private sector project supported by funding agencies and drugs companies including Glaxo Wellcome and HoffmanLa Roche (see Nature 395, 417; 1998).

Also active in this field is Multilateral Initiatives on Malaria, a consortium that includes the US National Institutes of Health, the Wellcome Trust, the World Bank and other UN agencies, which aims to develop malaria research in Africa.

The recent increase in collaborative ventures is a response to the fact that malaria parasites are becoming increasingly resistant to existing antimalarials, while the pharmaceutical industry has virtually abandoned research on tropical diseases (see Nature 386, 540; 1997).

The companies involved in JPMW Takeda, Eisai, Yamanouchi, Chugai, Shionogi, Fujisawa, Sankyo, Daiichi, Suntory, Yoshitomi, Dainippon and Sumitomo Pharmaceuticals - will provide compounds from their chemical libraries for antimalarial screening.

The molecules will be screened by the Kitasato Institute in Tokyo, which plans to carry out random testing of more than 12,000 molecules over the next five years. Kitasato will also screen more than 2,000 molecules from its own libraries. Any molecule showing activity in the screening will be followed up by WHO's Programme on Tropical Diseases Research.

Win Gutteridge, the programme's chief of product research and development, says that the tools are already available to reduce the burden of malaria mortality and morbidity. But halving the figures within a decade, the declared aim of the Roll Back Malaria programme, "will only be possible if new tools, including antimalarials, are developed”. Asako Saegusa 